\title{
The Seroprevalence of Hepatitis B Viral Infection in HIV Tested Positive Individuals in Owerri, Imo State, Nigeria
}

\author{
Nwako Okechukwu' ${ }^{\text {* }}$, Mbata Godwin ${ }^{1}$, Ofondu Eugenia1, Emeh Desmond ${ }^{2}$ and Obi Patrick ${ }^{1}$ \\ ${ }^{1}$ Department of Internal Medicine, FMC Owerri, Imo State, Nigeria \\ ${ }^{2}$ HIVIAIDS/STI\&STD Unit, Imo State Ministry of Health, Nigeria
}

\begin{abstract}
Background: The contribution of hepatitis B viral infection in HIV positive individuals is becoming increasingly recognized especially with the advent of Highly Active Antiretroviral drugs (HAART) which tend to prolong the life expectancy of HIV patients, thus increasing the tendency for chronic sequalae of hepatitis B in HIV/HBV co infection.
\end{abstract}

Method: A total of 300 HIV positive adults who were >18years and residing in Owerri were enrolled in this study. Participants were drawn from twenty (20) private laboratory services between January, 2013 and August, 2013.

Result: Out of the three hundred (300) individuals who tested positive for HIV, thirty two (32) persons (10.6\%) showed positive serology test for Hepatitis B in our series. Out of these persons, twenty one (21) $(65.6 \%)$ were females while eleven (11) $(34.4 \%)$ were males. Among the study population, persons aged $25-34.9$ years had the highest prevalence of co infection (56.25\%), while patients aged 55-64.9 years had the least prevalence. Males aged 35-44.9 years had the highest prevalence. Majority of the females were secondary school holders $(46.9 \%)$ who were selfemployed and having multiple unprotected heterosexual lifestyles.

Conclusions: HIV and Hepatitis B viral infections share common route of transmission and they synergistically accelerate each progression. Greater public health enlightenment in areas of health seeking behavior, safer sex practice, and overall health promotion must be intensified if reduction of this hepatitis B viral burden is to be achieved.

Keywords: Hepatitis B; Seroprevalence; HIV; Imo state; Nigeria

\section{Introduction}

The sub-Saharan Africa countries have a high burden of HIV patients [1]. Death attributable to this immunosuppressive illness is also high. Viral hepatitis particularly HBV infection is a major public health concern in the region as it affects an estimated population of 350 million and is the commonest cause of primary liver cell carcinoma in sub Saharan Africa [2]. HIV/AIDS and HBV share similar route of transmission and their impact has been persistently high in the sub-Saharan Africa. A person who is infected with both HIV and $\mathrm{HBV}$ is said to be HIV/HBV co-infected. The rate of progression and complications from viral hepatitis are accelerated in patients with HIV co-infection [3,4]. After acquiring HBV infection, HIV infected individuals become six times more likely to develop chronic HBV than HIV negative individuals [5-7]. Consequently there is increased morbidity and mortality from chronic liver disease among patients with HIV/AIDS. Nigeria is a very large country of about 167 million people with multiple ethnic groups, religion and cultural behaviors. The sero-prevalence of HIV/HBV has been studied in many parts of the country. HBV co-infection has been shown to occur in $10-70 \%$ of HIV infected individuals [8-10]. A cross sectional study of adult population more than 18 years in Lagos, Nigeria shows a sero-prevalence rate of $10 \%$ [2]. In Niger Delta, Ejele et al. got a prevalence of $9.7 \%$ among their HBV/HIV coinfected patients [10,11]. In Jos, Nigeria, Idoko got a prevalence rate of $16.7 \%$ while Nwokedi et al. in Kano got a very high prevalence of $70.5 \%$. In the developed countries like North America with low endemicity, the route of transmission is mostly sexual and percutaneous here the sero-prevalence of chronic HBV co-infection among HIV positive individuals is 5-7\% [12]. It is important to note that most of these studies were hospital based and most of the patients seen in the hospital are very sick patients. In Nigeria, where most of the patients finance their health bills, the health seeking attitude is variable depending on the income status, cultural values and religious belief of the patients. Many of the citizens prefer attending public laboratories before visiting the hospitals. Because of this growing concern, we therefore had to undertake this research project to investigate the seroprevalence of HIV/HBV infection in these populations who are using public laboratories. This strategy we believe will increase case finding within the population. The patient will be better counseled and possibly referred to appropriate facility where management can be obtained.

\section{Method}

This was a descriptive cross sectional study conducted between January 2013 and August 2013. Participants were drawn from twenty (20) different private medical laboratory facilities in Owerri, the state capital of Imo stat southeast Nigeria. The facilities were selected by simple random sampling. Patients whose HIV statuses were positive were enrolled for the study after obtaining informed consent. Pretest and post test counseling were given. The hepatitis B surface antigen screening test was rendered free to the subject. A total of three hundred (300) HIV positive individuals aged eighteen (18) years and older, residing within the study area, participated in the study. Pretested structured Self administered questionnaire were used to obtain the

*Corresponding author: Nwako Okechukwu, Department of Internal Medicine, Federal medical centre, Owerri, Imo State, Nigeria, Tel: +234-803-740-0054 E-mail: freeokey@yahoo.com

Received December 10, 2013; Accepted February 03, 2014; Published February 10, 2014

Citation: Okechukwu N, Godwin M, Eugenia O, Desmond E, Patrick O (2014) The Seroprevalence of Hepatitis B Viral Infection in HIV Tested Positive Individuals in Owerri, Imo State, Nigeria. J AIDS Clin Res 5: 273. doi:10.4172/2155 6113.1000273

Copyright: @ 2014 Okechukwu N, et al. This is an open-access article distributed under the terms of the Creative Commons Attribution License, which permits unrestricted use, distribution, and reproduction in any medium, provided the original author and source are credited. 
Citation: Okechukwu N, Godwin M, Eugenia O, Desmond E, Patrick O (2014) The Seroprevalence of Hepatitis B Viral Infection in HIV Tested Positive Individuals in Owerri, Imo State, Nigeria. J AIDS Clin Res 5: 273. doi:10.4172/2155-6113.1000273

Page 2 of 4

socio demographic parameters and risk factors for hepatitis B viral infection in the participants.

\section{Sample collection and processing}

$2 \mathrm{mls}$ of blood from patients who tested positive for HIV were drawn after obtaining informed consent, using a sterile syringe and needle. Samples were transferred into a universal glass container. These were adequately labeled and allowed to stand between 4-6 hours to obtain the sera. The sera were tested for hepatitis B surface antigen using HBsAg Rapid test Kit (Atlas Link Biotech Co, ltd) according to the manufacturer's direction. The rapid test kit method was used following Okogbo et al. [13] documentation and WHO 2006 guideline. The HBV testing kits used are based on the principle of sandwich immunoassay for determination of HBsAg in human serum or whole blood samples.

\section{Data analysis}

Data was analyzed using Statistical Package for Social Sciences (SPSS) version 16.0. Chi square was used to determine the level of association between individual variables and Hepatitis B co-infection. The prevalence of Hepatitis B co-infection was represented in percentage.

\section{Result}

Out of the three hundred (300) HIV positive participants, thirty two (32) $(10.6 \%)$ were positive for hepatitis B surface antigen (i.e. HIV/HBV co-infection) while two hundred and sixty eight (268) were negative for the screening. Among those with $\mathrm{HIV} / \mathrm{HBV}$ coinfection, twenty one (21) (65.6\%) were females while eleven (11) (34.4\%) were males. The highest prevalence of the co infection was seen among those aged 25-34.9 years $(56.25 \%)$ while the least was seen in those aged 55-64.9 years (3.13\%). Males aged 35-44.9 years had the highest prevalence for the male series. Majority of the females were secondary school holders $(46.9 \%)$ who were self employed $(31.25 \%)$ and having multiple unprotected heterosexual lifestyles (56.25\%). History of previous blood transfusion and injection drug use in females were $12.5 \%$ and $3.13 \%$ respectively and $6.25 \%$ and $9.4 \%$ for males respectively. There is no statistical significance $(\mathrm{p}>0.05)$ between Hepatitis B viral infection and the following (a) age-gender cross tabulation ( $\mathrm{p}$-value $=0.056$ ) (b) previous blood transfusioninjection drug use and gender $(\mathrm{p}=0.052)$ (c) education-gender cross tabulation $(\mathrm{p}=0.056)$ and $(\mathrm{d})$ sexual lifestyle-gender cross-tabulation (0.0714) (Table 1). However there is statistical significance $(\mathrm{p}<0.05)$

\begin{tabular}{|c|c|c|c|c|}
\hline $\begin{array}{c}\text { Ages (Years) } \\
\text { p-value= } 0.056\end{array}$ & No of Positive HBsAg & $\begin{array}{c}\text { Sex distribution among age brackets } \\
\text { \% }\end{array}$ & M \\
\hline $15-24.9$ & $4(1.33)$ & 12.50 & $3(\%)$ & $1(25)$ \\
\hline $25-34.9$ & $18(6.00)$ & 56.25 & $14(77.8)$ & $4(22.2)$ \\
\hline $35-44.9$ & $7(2.33)$ & 21.90 & $1(14.3)$ & $6(85.7)$ \\
\hline $45-54.9$ & $2(0.67)$ & 6.25 & $2(100)$ & $0(0)$ \\
\hline $55-64.9$ & $1(0.33)$ & 3.13 & $1(100)$ & $0(0)$ \\
\hline TOTAL & $\mathbf{3 2}(\mathbf{1 0 . 6 0 )}$ & & $\mathbf{2 1}$ & $\mathbf{1 1}$ \\
\hline
\end{tabular}

$\%^{1}=\%$ for coinfection cases only.

\begin{tabular}{|c|c|c|c|c|c|}
\hline \multicolumn{2}{|c|}{ Ages (years) p-value $=0.056$} & \multicolumn{2}{|c|}{ No of negative HBsAg } & \multicolumn{2}{|c|}{$(\%) \%^{1}$} \\
\hline \multicolumn{2}{|c|}{$15-24.9$} & \multicolumn{2}{|c|}{$80(26.67)$} & \multicolumn{2}{|c|}{29.90} \\
\hline \multicolumn{2}{|c|}{$25-34.9$} & \multicolumn{2}{|c|}{$90(30.00)$} & \multicolumn{2}{|c|}{33.60} \\
\hline \multicolumn{2}{|c|}{$35-44.9$} & \multicolumn{2}{|c|}{$80(26.67)$} & \multicolumn{2}{|c|}{29.90} \\
\hline \multicolumn{2}{|c|}{$45-54.9$} & \multicolumn{2}{|c|}{$12(4.00)$} & \multicolumn{2}{|c|}{4.50} \\
\hline \multicolumn{2}{|c|}{$55-64.9$} & \multicolumn{2}{|c|}{$6(2.00)$} & \multicolumn{2}{|c|}{2.23} \\
\hline \multicolumn{2}{|c|}{ Total } & \multicolumn{2}{|c|}{$268(89.40)$} & \multicolumn{2}{|c|}{100} \\
\hline \multirow[t]{2}{*}{ Sex } & \multicolumn{2}{|c|}{ HBsAg Positive $\left(\%^{1}\right)$} & \multicolumn{2}{|c|}{ HBsAg Negative } & Total No of Sex \\
\hline & $\%$ & $\%^{1}$ & $\%$ & $\%^{1}$ & \\
\hline Male & $11(3.67)$ & $(34.4)$ & $118(39.33)$ & $(44)$ & $129(43)$ \\
\hline Female & $21(7.00)$ & $(65.6)$ & $150(50)$ & $(56)$ & $171(57)$ \\
\hline Total & 32 & $(100)$ & 268 & $(100)$ & $300(100)$ \\
\hline
\end{tabular}

\begin{tabular}{|c|c|c|c|c|c|c|c|c|}
\hline \multirow{2}{*}{$\begin{array}{c}\text { Educational status } \\
p \text {-value }=0.056\end{array}$} & \multicolumn{4}{|c|}{ HBsAg positive cases } & \multicolumn{4}{|c|}{ HBsAg negative cases } \\
\hline & $F(\%)$ & $\%^{1}$ & M (\%) & $\%^{1}$ & $\mathbf{F}(\%)$ & $\%^{1}$ & M (\%) & $\%^{1}$ \\
\hline Primary & $2(0.67)$ & 6.25 & $5(1.67)$ & 15.63 & $20(6.67)$ & 7.5 & $40(13.33)$ & 14.90 \\
\hline Secondary & $15(5.00)$ & 46.90 & $4(1.33)$ & 12.50 & $90(30.00)$ & 33.6 & $40(13.33)$ & 14.90 \\
\hline Post-secondary & $4(1.33)$ & 12.50 & $2(0.67)$ & 6.25 & $40(13.33)$ & 14.90 & $38(12.67)$ & 14.18 \\
\hline Total & 21 & & 11 & & 150 & & 118 & \\
\hline \multicolumn{9}{|c|}{ Sexual lifestyle among coinfected individual $p$-value $=0.071$} \\
\hline \multicolumn{3}{|c|}{ Heterosexual } & \multicolumn{3}{|c|}{$18(56.25)$} & \multicolumn{3}{|c|}{$10(31.25)$} \\
\hline \multicolumn{3}{|c|}{ Use condom all the time } & \multicolumn{3}{|c|}{$4(19)$} & \multicolumn{3}{|c|}{$3(27.3)$} \\
\hline \multicolumn{3}{|c|}{ Homosexual } & \multicolumn{3}{|c|}{$3(9.4)$} & \multicolumn{3}{|c|}{$1(3.13)$} \\
\hline \multicolumn{3}{|c|}{ Bisexual } & \multicolumn{3}{|c|}{$3(9.4)$} & \multicolumn{3}{|c|}{$1(3.13)$} \\
\hline \multicolumn{3}{|c|}{ Sexually naïve } & \multicolumn{3}{|c|}{$3(9.4)$} & \multicolumn{3}{|c|}{-} \\
\hline
\end{tabular}




\begin{tabular}{|c|c|c|c|c|c|c|c|c|}
\hline $\begin{array}{c}\text { Occupation } \\
\text { p-value=0.031 }\end{array}$ & \multicolumn{3}{|c|}{ HBsAg positive cases } & \multicolumn{4}{c|}{ HBsAg negative cases } \\
\hline & $\mathbf{F ~ ( \% )}$ & $\%^{1}$ & $\mathbf{M}(\%)$ & $\%^{1}$ & $\mathbf{F ~ ( \% )}$ & $\%^{1}$ & $\mathbf{M}(\%)$ & \%1 \\
\hline Unemployed & $7(2.33)$ & 21.90 & $2(0.67)$ & 6.25 & $50(16.67)$ & 18.66 & $30(10)$ & 11.20 \\
\hline Student & $2(0.67)$ & 6.25 & $4(1.33)$ & 12.50 & $15(5.00)$ & 5.59 & $25(8.33)$ & 9.33 \\
\hline Self employed & $10(3.33)$ & 31.25 & $4(1.33)$ & 12.50 & $40(13.33)$ & 14.90 & $38(12.67)$ & 14.18 \\
\hline Public servant & $2(0.67)$ & 6.25 & $1(0.33)$ & 3.13 & $40(13.33)$ & 14.90 & $30(10)$ & 11.20 \\
\hline
\end{tabular}

$\%$ is calculated for positive (Coinfections) cases only

\begin{tabular}{|c|c|c|}
\hline \multicolumn{2}{|c|}{ Revious blood $\mathbf{p}$-value=0.052 } \\
\hline Transfusion & $4(12.5)$ & $2(6.25)$ \\
\hline Injection drug user & $1(3.13)$ & $3(9.4)$ \\
\hline
\end{tabular}

Table 1: Socio demographic features as it relates to HbsAg Sero-positivity.

between Hepatitis $\mathrm{B}$ viral infection and occupation with respect to gender $(\mathrm{p}=0.031)$.

\section{Discussion}

The prevalence of hepatitis B among the HIV patients studied in our series was $10.6 \%$. This was similar to the result of many related studies done within and outside Nigeria $[8-11,14,15]$. However, the result differs from few studies in Nigeria $[5,16,17]$. In a cohort of 260 HIV adult patients studied in National Hospital Abuja Nigeria, the prevalence of HBV/HIV co-infection was $11.5 \%$ [14]. In Ibadan Nigeria, a retrospective study of 1779 HIV infected patients studied showed HBsAg sero-positivity of $11.9 \%$ [11] while in Lagos Nigeria, a cross sectional study of 8309 consented HIV infected individuals aged 18 years and above, carried between 2006 and 2009 showed a prevalence of $10 \%$ [15]. In Orlu, Diwe et al. [18] reported a prevalence of $2.2 \%$. Orlu is a suburban area in Imo state, and the difference in our studies may be due to rapid urbanization and behavioral change or equally due to the facilities used for the studies. However, in Nnewi, southeast Nigeria, a retrospective study of 1176 HIV infected subjects showed HBsAg seropositivity of $6.3 \%$ [16] while in Jos Nigeria, Uneke et al. reported prevalence of $6.3 \%$ [5,17]. Another scholar in Jos found a higher prevalence of $16.7 \%$ [19] and differences may be due to population size. In Kano, another northern part of Nigeria, very high prevalence rate of $70.5 \%$ was seen [15]. In Niger delta region of the country, prevalence of $9.7 \%$ was also documented [10]. In a similar study in Tanzania, outside of Nigeria involving a cohort of 17,539 of HIV infected individuals, $6.2 \%$ were co-infected with hepatitis B [20]. Braga et al. in a similar study in Brazil, got a prevalence of $5.7 \%$ which is lower than the prevalence obtained in our study [21]. A US cohort of HIV infected individuals during the past 20 years using 2769 participant showed a prevalence of $39 \%$ (1078/2769), of whom $11 \%$ had chronic hepatitis B viral infections. However there has been a decline in the US on the overall prevalence over the past two decades [22]. In countries with intermediate and high HBV endemicity, the main routes of transmission of $\mathrm{HBV}$ are perinatal or in early childhood; in these countries HBV coinfection rates are 10-20\% [23-25]. In Nigeria, a country where HBV and HIV infection prevalences are high, HBV coinfection occurs in $10-70 \%$ of HIV infected individuals [8-11] $[10,16,22,26]$. Our study supported the observation made by these scholars. It seems likely that the prevalence rate of $\mathrm{HIV} / \mathrm{HBV}$ coinfection is increasing from southern to the northern part of Nigeria among adult populations. In pediatric population, a study of $139 \mathrm{HIV}$ infected children demonstrated a prevalence of $5.8 \%$ in our locality at Owerri [26]. We found higher female (65.6\%) to male prevalence (34.4\%) ratio, (1.90:1) which differ with findings from Okocha et al. and Otegbayo et al. $[11,16,20,26]$. In a study of $260 \mathrm{HIV}$ positive patients in Abuja, Nigeria, higher female preponderance for HIV/HBV coinfection was demonstrated [14] and this supported our findings. We demonstrated that the participants aged 25-34.9 years had the highest frequency of HBV/HIV coinfection, which was similar to Adewole et al. [14] who reported similar age range (30-39 years). Okocha [16] showed that those aged $20-29$ years constituted $43.6 \%$ of their subject and represented the highest age range. In our series, we demonstrated a decreasing prevalence of HBsAg positivity with age. This could be accounted for by the likely many route of transmission which operates in the younger age group with apparent clearing of the infection in older group or death leaving between $5-10 \%$ as chronic carriers in older population. Unprotected heterosexual lifestyle among the population most affected, was associated with route of transmission. Only 19\% of affected female and $27.3 \%$ of affected males use condom consistently. However, the role of vertical transmission could account for the level of seropositivity as we reside in area of high endemicity, but this claim was not pursued. A larger proportion of those co-infected with HBV/ HIV in Adewole's study had a history of scarification marks (50\%) and multiple blood transfusions (25\%) with no case of IV drug abuse in any of the groups while in our series, previous blood transfusion accounted for $12.5 \%$ and $6.25 \%$ in females and males respectively. Unlike, report of Adewole in 2009, we recorded a case (3.13\%) and 3 cases $(9.4 \%)$ of injection drug use in Owerri in females and males respectively. This difference may be accounted for by the adoption of western lifestyle which is fastly encroaching in our society, but linking them as the source of hepatitis B in these subjects is not as simple. The co-infection of hepatitis B and HIV has been shown to accelerate the progression and complication of HBV replication [3,4]. This has been shown to cause loss of previously developed protective anti-HBs antibody leading to development of acute hepatitis B infection in HIV patients; this risk is also associated with lower CD4 counts [27,28]. Also, following initiation of antiretroviral therapy (ART), immune reconstitution inflammatory syndrome (IRIS) may occur which can lead to worsening liver disease including hepatic decompensation [29].

\section{Conclusion}

Obviously the prevalence of HIV/HBV co-infection has been shown to be high in Nigeria likely due to the shared common route of transmission. Greater public health enlightenment in health seeking behavior, safer sex practice and overall health promotion must be intensified if reduction of this hepatitis $B$ viral burden is to be achieved. The HBV vaccination should be intensified among individuals who are at risk of acquiring hepatitis $\mathrm{B}$ virus.

\section{Acknowledgements}

We wish to acknowledge the following laboratories for allowing us use their facilities for this research. All are located within Owerri zone. 

1) Welfare medical laboratories (6 annexes).
2) Links laboratories (4 annexes).
3) Dalzon medical laboratories (5 annexes)
4) Cornerstone diagnostic laboratory (5 annexes).

\section{References}

1. Muuala AS (2000) Tackling HIV and AIDS in Africa- another perspective. Africa Health 23: 5-6.

2. Lavanchy D (2004) Hepatitis B virus epidemiology, disease burden, treatment, and current and emerging prevention and control measures. J Viral Hepat 11: 97-107.

3. Puoti M, Cozzi-Lepri A, Paraninfo G, Arici C, Moller NF, et al. (2006) Impact of lamivudine on the risk of liver-related death in 2,041 HBsAg- and HIV-positive individuals: results from an inter-cohort analysis. Antivir Ther 11: 567-574.

4. Thio CL (2009) Hepatitis B and human immunodeficiency virus coinfection. Hepatology 49: S138-145.

5. Bodsworth NJ, Cooper DA, Donovan B (1991) The influence of human immunodeficiency virus type 1 infection on the development of the hepatitis $B$ virus carrier state. J Infect Dis 163: 1138-1140.

6. Gatanaga H, Yasuoka A, Kikuchi Y, Tachikawa N, Oka S (2000) Influence of prior HIV-1 infection on the development of chronic hepatitis B infection. Eur $J$ Clin Microbiol Infect Dis 19: 237-239.

7. Hadler SC, Judson FN, O'Malley PM, Altman NL, Penley K, et al. (1991) Outcome of hepatitis $B$ virus infection in homosexual men and its relation to prior human immunodeficiency virus infection. J Infect Dis 163: 454-459.

8. Iwalokun BA, Hodonu SO, Olaleye BM, Olabisi OA (2006) Seroprevalence and biochemical features of hepatitis B surface antigenemia in patients with HIV-1 infection in Lagos, Nigeria. Afr J Med Med Sci 35: 337-343.

9. Nwokedi EE, Emokpae MA, Dutse AI (2006) Human immunodeficiency virus and hepatitis $B$ virus co-infection among patients in Kano Nigeria. Niger J Med 15: $227-229$.

10. Ejele OA, Nwauche CA, Erhabor O (2004) The prevalence of hepatitis B surface antigenaemia in HIV positive patients in the Niger Delta Nigeria. Niger J Med 13: 175-179.

11. Otegbayo JA, Taiwo BO, Akingbola TS, Odaibo GN, Adedapo KS, et al. (2008) Prevalence of hepatitis B and C seropositivity in a Nigerian cohort of HIVinfected patients. Ann Hepatol 7: 152-156.

12. Alter MJ (2006) Epidemiology of viral hepatitis and HIV co-infection. J Hepatol 44: S6-9.

13. Okogbo FO, Aisabokhale FA, Dada FL (2004) Journal of Applied and Basic Sciences 2: 33-35.

14. Adewole OO, Anteyi E, Ajuwon Z, Wada I, Elegba F, et al. (2009) Hepatitis B and $C$ virus co-infection in Nigerian patients with HIV infection. J Infect Dev Ctries 3: 369-375.

15. Odunukwe N, Okwuozo J, Somefun E, Musa Z, Ezeobi P, et al. (2011) The prevalence and risk factors of HBV/HIV coinfection in Lagos, Nigeria. 6th IAS conference on HIV Pathogenesis and Treatment: Abstract no CDB168.

16. Okocha EC, Oguejiofor OC, Odenigbo CU, Okonkwo UC, Asomugha L (2012) Prevalence of hepatitis B surface antigen seropositivity among HIV-infected and non-infected individuals in Nnewi, Nigeria. Niger Med J 53: 249-253.

17. Uneke CJ, Ogbu O, Inyama PU, Anyanwu GI, Njoku MO, et al. (2005)
Prevalence of hepatitis-B surface antigen among blood donors and human immunodeficiency virus-infected patients in Jos, Nigeria. Mem Inst Oswaldo Cruz 100: 13-16.

18. Chiekulie Kevin Diwe, Emmanuel Chidiebere Okwara, Oguamanam Okezie Enwere, Jerome Emeka Azikiwe, Nathan Chibuzo Nwaimo (2013) Seroprevalence of hepatitis B virus and hepatitis $C$ virus among HIV patients in a suburban University Teaching Hospital in south eas, Nigeria. The pan African Medical Journal 16: 7.

19. Idoko J, Meloni S, Muazu M, Nimzing L, Badung B, et al. (2009) Impact of hepatitis $B$ virus infection on human immunodeficiency virus response to antiretroviral therapy in Nigeria. Clin Infect Dis 49: 1268-1273.

20. Hawkins C, Christian B, Ye J, Nagu T, Aris E, et al. (2013) Prevalence of hepatitis B co-infection and response to antiretroviral therapy among HIVinfected patients in Tanzania. AIDS 27: 919-927.

21. Braga WS, da Costa Castilho M, dos Santos IC, Moura MA, Segurado AC (2006) Low prevalence of hepatitis B virus, hepatitis D virus and hepatitis $C$ virus among patients with human immunodeficiency virus or acquired immunodeficiency syndrome in the Brazilian Amazon basin. Rev Soc Bras Med Trop 39: 519-522.

22. Chun HM, Fieberg AM, Hullsiek KH, Lifson AR, Crum-Cianflone NF, et al (2010) Epidemiology of Hepatitis B virus infection in a US cohort of HIV-infected individuals during the past 20 years. Clin Infect Dis 50: 426-436.

23. Diop-Ndiaye H, Touré-Kane C, Etard JF, Lô G, Diaw P, et al. (2008) Hepatitis $B, C$ seroprevalence and delta viruses in HIV-1 Senegalese patients at HAART initiation (retrospective study). J Med Virol 80: 1332-1336.

24. Lee HC, KO, Ny Lee Ny (2008) Seroprevalence of viral hepatitis and sexually transmitted disease among adults with recently diagnosed HIV infection in southern Taiwan, 2000-5 (2008): Upsurge in hepatitis C virus infections among injection drug users. J formos Med Assoc 107: 404-411.

25. Nyirenda M, Beadsworth MB, Stephany P, Hart CA, Hart IJ, et al. (2008) Prevalence of infection with hepatitis $B$ and $C$ virus and coinfection with $\mathrm{HIV}$ in medical inpatients in Malawi. J Infect 57: 72-77.

26. Emeka Nwolisa, Francis Mbanefo, Joseph Ezeogu, Paul Amadi (2013) prevalence of hepatitis $\mathrm{B}$ coinfection amongst HIV infected children attending a care and treatment centre in Owerri, southeastern Nigeria. Pan Afr Med J 14: 89.

27. Biggar RJ, Goedert JJ, Hoofnagle J (1987) Accelerated loss of antibody to hepatitis $B$ surface antigen among immunodeficient homosexual men infected with HIV. N Engl J Med 316: 630-631.

28. Laukamm-Josten U, Müller O, Bienzle U, Feldmeier H, Uy A, et al. (1988) Decline of naturally acquired antibodies to hepatitis $B$ surface antigen in HIV-1 infected homosexual men. AIDS 2: 400-401.

29. Drake A, Mijch A, Sasadeusz J (2004) Immune reconstitution hepatitis in HIV and hepatitis B coinfection, despite lamivudine therapy as part of HAART. Clin Infect Dis 39: 129-132. 